\title{
PERFORMANCE-BONUS CONTRACT IN LIGHT OF IFRS 15 AND THE POLISH ACCOUNTING ACT
}

\begin{abstract}
The conditional element of the price included in the performance-bonus contract is a frequent component of contracts concluded with customers in some sectors. It is a deferred component of the price, which may never (in whole or in part) become a consideration due. Due to lack of unambiguous provisions in this respect in Polish domestic law and the entry into force of IFRS 15, the author raises the issue of accounting for such defined revenues. The aim is to analyze the provisions of IFRS 15 in the scope of a delivery contract with a performance bonus against the background of the provisions of the Polish Accounting Act. The verified thesis assumes that, although both regulations are consistent with the theoretical foundations of accounting, each of them differently recognizes the above-mentioned revenues. The goal was achieved by analyzing the regulations of IFRS 15, Polish Accounting norms and the presentation of a case study. The results confirmed a different recognition of revenues based on two analyzed legal regulations and indicated a large role of estimates in terms of revenue disclosures under IFRS 15.
\end{abstract}

Keywords: revenues, IFRS 15, performance-bonus contract.

\section{INTRODUCTION}

The usual claim is that the implementation of the new International Financial Reporting Standard 15 "Revenue from contracts with customers" (IFRS $15^{2}$ ) mainly changes the rules for recognizing revenues from contracts in which both services and delivery of goods occur. The basic assumption of the standard is the recognition of revenues in a manner presenting the amounts that the entity expects in connection with the transfer of goods and/or provision of services. The indicated approach poses new challenges for accounting services, therefore the purpose of the paper is to analyze the provisions of IFRS 15 and the Polish Accounting Act (the $\mathrm{Act}^{3}$ ) for the selected type of contracts with customers: contracts for the supply of goods (provision of services) along with a bonus for achieving the performance specified in the contract. A special feature of performance-bonus contracts is the payment of a bonus after meeting a certain condition for which the probability of occurrence is not equal to

\footnotetext{
${ }^{1}$ Ewa Wanda Maruszewska, DSc, PhD, Associate Prof. Business Informatics and International Accounting Department, University of Economics in Katowice, street Bogucicka 3 (budynek A), 40-287 Katowice, e-mail: ewa.maruszewska@ue.katowice.pl.

Dr hab. Ewa Wanda Maruszewska, prof. UE, Katedra Informatyki i Rachunkowości Międzynarodowej, Uniwersytet Ekonomiczny w Katowicach, Katowice, ul. Bogucicka 3 (budynek A), 40-287 Katowice, e-mail: ewa.maruszewska@ue.katowice.pl

2 International Financial Reporting Standard No 15 Revenues From Contracts With Customers, International Accounting Standard Board, London 2014.

${ }^{3}$ Ustawa z 29 września 1994 roku o rachunkowości (tekst jedn. Dz.U. z 2017 r., poz. 2342 ze zm.).
} 
$100 \%$. To achieve the goal, the author used the analysis of IFRS 15 and the Act regulations as well as the presentation of a case study based on business practice. The reasoning regarding the disclosure of revenue from the performance-bonus contract was referred to the conceptual assumptions of accounting. The conclusions raised the possibility of a different recognition of revenues based on two analyzed legal regulations and indicated a significant share of estimates in the disclosure of revenues under IFRS 15.

\section{CHARACTERISTICS OF PERFORMANCE-BONUS CONTRACTS}

In accordance with contractual freedom in the course of trade, it is possible that the parties to the contract agree on a price for the transfer of goods (and/or services) consisting of two elements:

- a fixed part, i.e. basic consideration and

- a variable part depending on the effect (realization), i.e. variable consideration. Contracts with the above distinction are common in the field of, e.g. services for preparing applications for EU funds, or consulting services, including tax and legal services. In the mentioned cases, the service provider is entitled to additional consideration after the occurrence of the benefits for the recipient specified in the contract in the form of, for example:

1) receiving funding from $\mathrm{EU}$ funds,

2) winning a legal case,

3) receiving a favorable tax law interpretation, or

4) validation of a positive administrative decision.

In the absence of the performance specified in the contract, the price payable is only equal to part of the basic consideration, the purpose of which is to cover (in part or in whole) the costs of the customer in terms of, inter alia:

1) preparation of application documentation for EU funding,

2) time of employees to prepare documentation and represent the customer in court,

3) preparation of a letter filed in connection with a request for tax interpretation,

4) preparation of documentation necessary for applying for a specific administrative decision.

The fixed amount of consideration independent of the fulfillment of the contractual condition may also include profit for the service provider. In this case, the entire premium, due after the condition defined by the contract is met, will be an additional performance bonus.

The subject of a detailed analysis of legal provisions in this paper is a contract whose object is to design and manufacture a machine in accordance with the requirements specified by the customer. The consideration indicated in the contract consists of three parts: 1) an element of fixed consideration for the service of designing a machine (PLN 800), which is due along with the approval of the project by the customer,

2) an element of fixed consideration for machine production (PLN 1,500), which is due along with delivery of the product to the customer's confirmed by the acceptance protocol of the machine and

3 ) the performance bonus, which is defined as $10 \%$ percent of the fixed consideration (PLN 230) and which is due after meeting certain technical requirements regarding the machine's efficiency and its consumption of electricity. 
The fulfillment of the condition necessary to receive the bonus will be possible only within two months of the transfer of the fixed asset to the customer. After the protocol statement of the occurrence of the result specified in the contract, the performance bonus will have a definitive and unconditional character.

The subject of the contract is a highly specialized machine tailored to the special requirements of the customer and is not in the general market circulation. It is not possible to sell the machine to another customer or to modify the product in such a way that it is suitable for resale in the event of withdrawal from the contract of the current customer. In connection with the above, the contract provides for a penalty for the customer's withdrawal from the contract after accepting the design of the machine in the amount equal to the fixed consideration specified in the contract.

\section{RULES FOR RECOGNIZING REVENUES IN ACCORDANCE WITH THE PROVISIONS OF THE ACCOUNTING ACT}

Revenues in the Act are defined as the likely occurrence of economic benefits in the reporting period, with a reliably determined value, in the form of an increase in the value of assets, or a reduction in liabilities that will lead to an increase in equity or a reduction in its shortfall in other ways than the contribution of funs by shareholders or owners. This definition is modeled on the International Accounting Standard No. 18 "Revenue" binding until the end of 2017 (IAS 184) and is consistent with the balance sheet approach to presenting information in the financial statements and granting priority to assets that are considered to be verifiable and measurable ${ }^{5}$. Although the above definition refers to future economic benefits, its core refers to ex post revenues ${ }^{6}$, which result from past business operations and are traceable, and reliably measurable with some estimates that can cause subjective judgments.

The basic issue of recognizing revenue in accounting is the date of posting revenue in accounting books. Replaced by IFRS 15, IAS 18 indicated that revenue is recognized when it is probable that in the future the entity will obtain economic benefits that can be measured reliably. The Act in the current wording, though modeled on IAS 18, does not indicate the point at which revenue should be considered due. Thus, Article 6 of the Act is of fundamental importance, as it states that the financial result should include all revenues related to the entity and costs related to these revenues attributable to the entity, for a given financial year, regardless of the date of their payment. Although granting the status of income earned (on accrual basis) belongs to the management of the entity, it is helpful to refer to the Civil $\mathrm{Code}^{7}$, according to which the benefit is due (payable) if there is

${ }^{4}$ International Accounting Standard No 18 Revenues, International Accounting Standard Board, London 1993.

5 K. Holmes, The concept of income. A multi-disciplinary analysis, Doctoral Series. IBFD Publications BV, Amsterdam, 2001, p. 125.

${ }^{6}$ H.G. Bullen, K. Crook, Revisiting the Concepts. A New Conceptual Framework Project. Communication Paper, Financial Accounting Standards Board \& International Accounting Standards Board, May 2005, p. 7.

${ }^{7}$ Ustawa z 23 kwietnia 1964 r. - Kodeks cywilny (tekst jedn. Dz.U. z 2017 r, poz. 459 ze zm.); Z. Radwański, Prawo cywilne - część ogólna, Warszawa 2009; Z. Radwański, A. Olejniczak, Zobowiązania - część ogólna, Warszawa 2010. 
a performance obligation which is a natural consequence of the sale contract. In addition, the Code indicates that the benefit specified in the contract concluded between the parties becomes due at the time agreed by the parties to the contract, e.g. by sending a sales invoice for a specific part of the price.

When analyzing the described case of a contract with fixed elements of the consideration and performance bonus, it should be pointed out that the fixed amounts of consideration in the period in which the service was rendered (product delivered) are clearly recognized in revenues, which is confirmed in the relevant protocol signed by both parties to the contract. The moment of rendering service (delivery of goods) determines the day on which the benefits and burdens associated with this item are passed on to the buyer, and during this period they are subject to recognition in the accounting books.

In terms of the performance bonus, under the Act, the revenue cannot be confirmed until the effect specified in the contract is achieved. Thus, the probable revenue that an entity expects to achieve - assuming that the required technical parameters will be met - is an element of contingent liabilities and as such may be subject to recognition in the off-balance sheet "contingent assets" in the projected amount considering the probability of meeting the condition specified in the contract. In the described case, it is also possible to draw up a contract in which the parties recognize the right to a part of the premium if the product delivered meets the technical requirements set in certain ranges. Then it is possible to pay the bonus partially. Contingent assets indicate the existence of possible assets that arise as a result of past events (here: the contract for designing and delivering the machine in accordance with the customer's requirements) and whose confirmation is possible only when one or more uncertain events occur or do not occur, which are not fully controlled by the entity (IAS $37^{8}$ ).

It also follows from the foregoing that the described case of dependence of consideration on fulfillment of a given condition does not constitute prerequisites for settling interim revenue, inter alia, due to the conditional nature of the receivables.

Summing up, the regulations of the Act point to the compulsory recognition of undoubted revenues, which - in the analyzed case - consist of fixed consideration elements. The performance bonus will be classified as revenue only after the effects described in the contract have been met. Until the explanation, regardless of the probability of fulfilling the prerequisites for determining the performance bonus, the amount due is treated as a conditional asset. The above solution is also consistent with the realization principle, which, although not explicitly included in current provisions of the Act, has long been the subject of discussion in the literature ${ }^{9}$. The realization principle requires recognition of revenue in the accounting books only at the time of sale, that is after the delivery of the item

${ }^{8}$ International Accounting Standard No 37 „Provisions, Contingent Liabilities and Contingent Assets, International Accounting Standard Board, London 1998.

${ }_{9}$ I. Toshio, Significance of realization principle in accounting, „,The Annals of the Hitotsubashi Academy" 1959, 9, p. 194-204.

Ch.T. Horngren, How should we interpret the realization concept?, „The Accounting Review” 1965, 40, p. 323-333.

R. Antle, J.S. Demski, Revenue recognition, „Contemporary Accounting Research” 1989, 5, p. $423-451$.

C. van Mourik, Y. Katsuo, Articulation, profit or loss and OCI in the IASB Conceptual Framework: different shades of clean (or dirty) surplus, Paper for the IASR Research Forum, Brussel, 28.11.2017. 
or meeting the obligation, which ensures that only the profits recorded in accrual accounting are recognized in the financial statements.

In the light of the above considerations, there is also the issue of matching revenues and costs, especially when the premium becomes due in a fiscal year other than fixed consideration elements. Owning to the conditional nature of the bonus, it is appropriate to allocate the costs incurred (directly and indirectly related to the performance of the contract concluded with the customer) to the unconditional revenues of the financial year in which they became due. From the point of view of financial accounting and the financial reports created on its basis, the proposed approach may result in understating the financial result in the year of execution of the contract, while showing revenue without matching costs in the year of receiving the bonus. Nonetheless, this solution seems to be correct, especially in the light of the prudence principle required by the provisions of the Act.

\section{IFRS 15 GUIDELINES ON THE RECOGNITION OF REVENUES IN THE FINANCIAL STATEMENTS}

The purpose of IFRS 15 is to provide users of financial statements with useful information on the nature, amounts, distribution over time and uncertainty as to revenues and cash flows resulting from contracts with customers. Although the term "revenues" is used in the title of IFRS 15, the standard does not include the definition of the term. In the discussion paper on the theoretical foundations ${ }^{10}$ published by the International Accounting Standards Board (the IASB), it is highlighted that this basic measurement parameter of entities' performance will not be defined at the level of standards, but precisely in the "Accounting Concepts and Principles" (CAP). The project underlines the continuation of the current approach to defining revenues. Still, this term refers to the consequences of changes in assets and liabilities resulting in an increase in equity other than contributions from existing and/or new owners (CAP, 2010). Thus, revenues (along with matching costs) are information about the profitability achieved by the entity using the resources it controls. In addition, the aim is to provide information useful for estimating future cash flows and to assess activities of the management who have been entrusted with the resources of the entity. This approach to revenues highlights the supremacy of the usefulness of information presented in financial statements over other qualitative attributes attributed to financial reports. At the same time, the IASB draws attention to the fact that maintaining the current definition does not mean giving primacy to the statement of comprehensive income from all elements of the financial statements, in particular against the balance sheet for providing useful information ${ }^{11}$. Each time, indicating the rules for disclosure of individual elements of the financial statements, the IASB analyzes the standards created in terms of providing useful information about both the financial situation (presented in the balance sheet) and the entity's performance (presented in the statement of comprehensive income), because the most important goal of preparing financial statements is to create information useful to its users.

\footnotetext{
${ }^{10}$ Exposure Draft. Conceptual Framework for Financial Reporting, International Accounting Standard Board, London 2015, p. 54.

${ }^{11}$ Basis for Conclusions. Exposure Draft ED/2015/3. Conceptual Framework for Financial Reporting, International Accounting Standard Board, London 2015, p. 33.
} 
Moreover, defining revenues in relation to changes in assets and liabilities results from the belief that the financial statements are to inform about economic operations that took place in the entity and whose knowledge is useful to the user of financial statements. Therefore, disclosing information about revenues as a consequence of transactions carried out is connected with the necessity to indicate assets and/or liabilities that have changed as a result of a given operation.

In order to disclose revenues from contracts with customers, an analysis involving five steps is required:

1) identification of the contract,

2) identification of obligations to perform as a consequence of the conclusion of the contract,

3) determination of consideration (transaction price),

4) assigning the consideration (transaction price) to the obligations to be performed,

5) fulfillment of obligations to be performed.

Taking into account the purpose of the paper, one should pay attention to several conditions resulting from the described case study. In the indicated case, the obligation to be performed includes both services in the form of machine design and transfer of rights to goods to be delivered in the future (handover of the machine). Two identified assignments to be performed are one obligation (performance) or they can be considered as two different benefits for which the entity is bounded under the contract. To make this decision, it is necessary to check whether:

- it can be expected in relation to the various obligations identified in the contract that the customer will benefit from the good (service) to be obtained, and

- the entity's obligation to transfer the good (providing the service) to the customer can be identified as separate from other obligations specified in the contract.

In the analyzed case, there is no situation to meet both of the above conditions, and this requires IFRS 15 to recognize each liability as a separate service. Therefore, it cannot be said that the customer will benefit from the machine design prepared for their needs, because the project will not find buyers on the market, even if the customer decided to sell it, in other words to benefit directly. Additionally, the purpose of the design service is to adapt another good (machine) promised in the contract, and this good is highly dependent on the service, which is one of the elements of the contract.

In the next step, apart from determining the amount of consideration for which the algorithm should result from the contract, the probability of receiving the amount of consideration specified in the contract should be assessed taking into account intention of the other party to pay a specific amount in due time. The transaction price in the analyzed case is the sum of two elements of consideration and has a value of PLN 2,300, unless the contract duration is long, the time value of money or the presence of a significant element of financing should be considered when estimating the amount of revenue. In other words, a fixed consideration consists of a fixed component and variable one, which is not subject to recognition due to its conditional nature and lack of certainty as to its achievement. The inclusion of the performance bonus is possible only in the situation of a high probability that the specified execution of the contract will occur and the entity is convinced that the revenue will not be reduced by the conditional part of the consideration, i.e. the realization of the effect is not dependent on factors beyond the control of the entity. Otherwise, the performance bonus is included in revenue only when it becomes due. 
Earlier recognition of the performance bonus is also possible in part if the contract provides for consideration for partial performance. In this case, it is possible to recognize the premium in the amount of the estimated transaction price. The condition, however, is the high probability that the performance bonus in the estimated amount will not be reduced and will become payable due. The estimate of this element of the price is made in accordance with the expected value method or the adoption of the most appropriate estimate.

Assigning the transaction price to the obligations to perform the service in the analyzed case means the division of the determined price to the individual stages of the contract. As previously agreed, the performance bonus will not be assigned because it is part of a price that is unlikely to be received.

If the premium is included in the transaction price value (in whole or in part), two approaches are possible. The entity, based on the circumstances and terms of the contract, states that it is not subject to assignment to a specific obligation because it refers to the entire contract and not to a given obligation (part of the contract) prior to the date of performance guaranteeing the payment of the bonus. When the premium becomes due, the entity should allocate its value over the entire term of the contract ${ }^{12}$. In the second case, the entity may assign a performance bonus to each liability based, e.g. on the share of this part of the benefit in completing the contract and fulfillment of the performance bonus.

The above is consistent with the indication that the entity recognizes revenues when the obligation to perform the service/transaction is met (or in the course of fulfillment) by transferring the promised goods or service (i.e. an asset) to the customer. Since the statement of comprehensive income is the basic source of information about the entity's performance, revenue is required, except for the exceptional cases described in the conceptual assumptions ${ }^{13}$. In these rare cases, the purpose of not disclosing revenue is to increase the usability of financial statements. In other words, possible deviations concern situations in which placing information about revenues would reduce the usefulness of reports in connection with, for example, misleading the users.

The IASB emphasizes that revenue recognition must correspond at the same time to the recognition of assets and/or liabilities that change in connection with an economic operation resulting in the appearance of revenues. The disclosure of assets and/or liabilities related to a given revenue must meet the definition of these categories, which are concepts not only in the scope of accounting, but in the wider economy ${ }^{14}$.

In the analyzed case, the obligations constituting the subject of the contract are met in time, and not only at the specified moment of the entire contract, as confirmed by the relevant protocols listed in the case study description. Although all elements of the contract were considered as one entity's obligation in the analyzed case study, revenues will be disclosed as the obligations of the assignments are fulfilled, that is, in the realizations

12 The new revenue recognition standard - brokers and dealers in securities. Technical Line. FASB - final guidance. Ernst \& Young, 2014. p. 8.

${ }^{13}$ Exposure Draft. Conceptual Framework for Financial Reporting, International Accounting Standard Board, London 2015, p. 93.

Conceptual Framework for Financial Reporting 2010. International Accounting Standards Board, 09'2010.

${ }^{14}$ Basis for Conclusions. Exposure Draft ED/2015/3. Conceptual Framework for Financial Reporting, International Accounting Standard Board, London 2015, p. 34. 
specified in the contract, as a result of which the entity has a present right to the payment for the asset and the customer controls the improved asset component. The purpose of this approach is to accurately reflect the degree of executing the obligation.

\section{CONCLUSIONS}

The analysis of the revenue recognition based on a case study taken from business practice indicates a similar approach to revenue with a great deal of scope for freedom under IFRS 15 as compared to the regulations of the Accounting Act. In particular, decisions should be made regarding:

- considering each obligation separately or as one obligation of the entity to perform the service/transaction,

- time and amount of the disclosed revenue.

Referring to the case study analysed in the paper, figure 1 presents the most probable recognition of revenues over time.

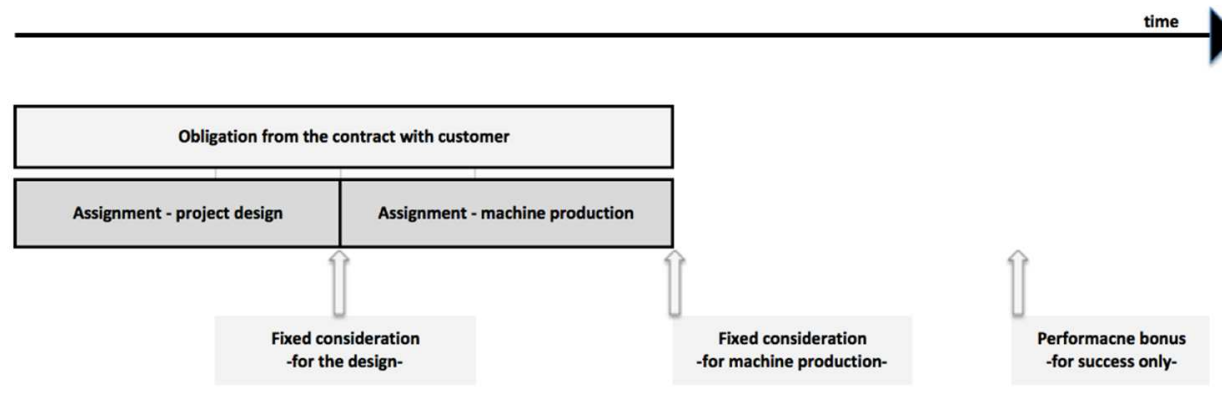

Fig. 1. Recognition of the revenue in the analyzed case study in accordance with the Act

According to the Act performance bonus will be recognized as revenue at the time of meeting certain technical requirements, as shown in Fig. 1. On the other hand, the above timeframe for revenues might be valid under IFRS 15, but it is also possible that the entity recognizes the bonus overtime during the realization of the contract. Moreover, under IFRS 15 it is possible to employ discounting in the revenue measurement when the entity decides that contract duration is long. The inclusion of estimates in the revenue disclosure process is particularly evident in the performance bonus, in which recognition in accordance with the Act may differ significantly from the presentation in accordance with IFRS 15.

Although this was not discussed in this paper, in the context of the described case study, it is worth noting that the new IFRS 15 standard may affect the capitalization of more costs than previously and charging them with the amount of profit or loss only at the recognition of revenue. This applies to the costs of securing the contract and the costs of completing the contract, which until now were treated as the costs of the period, rather than substantially appropriate costs.

From the above considerations it can be concluded that changes in the scope of IFRS go towards guidelines and principles that should be followed, reducing the number of rigid rules. Recognition of revenues under IFRS 15 is a presentation of future projected results and effects of concluded contracts, not a reflection of historical values resulting from 
invoices issued. These changes coincide with giving the primacy of utility, while credibility is a secondary feature. The above, together with the revenue recognition depending on the business model and the inclusion of the time value of money into revenue estimates, indicates a departure from historical value in favor of fair value, which is in line with the general trend of changes in international accounting. On the other hand, the convergence of IFRS with the Act has been weakened, which may result in difficulties for Polish entities in obtaining foreign capital.

\section{REFERENCES}

1. Exposure Draft, Conceptual Framework for Financial Reporting, International Accounting Standard Board, London 2015.

2. Antle R., Demski J.S., Revenue recognition, „Contemporary Accounting Research” 1989, 5.

3. Basis for Conclusions. Exposure Draft ED/2015/3. Conceptual Framework for Financial Reporting, International Accounting Standard Board, London 2015.

4. Bullen H.G., Crook K., Revisiting the Concepts. A New Conceptual Framework Project, Communication Paper, Financial Accounting Standards Board \& International Accounting Standards Board, May 2005.

5. Conceptual Framework for Financial Reporting 2010, International Accounting Standards Board, 09'2010.

6. Holmes K., The concept of income. A multi-disciplinary analysis, Doctoral Series. IBFD Publications BV, Amsterdam, 2001.

7. Horngren Ch.T., How should we interpret the realization concept?, „The Accounting Review" 1965, 40.

8. International Financial Reporting Standard No. 15 Revenues From Contracts With Customers, International Accounting Standard Board, London 2014.

9. International Accounting Standard No. 18 Revenues, International Accounting Standard Board, London 1993.

10. International Accounting Standard No. 37 „Provisions, Contingent Liabilities and Contingent Assets, International Accounting Standard Board, London 1998.

11. Radwański Z., Prawo cywilne - czesść ogólna, C.H. Beck Publisher, Warszawa 2009.

12. Radwański Z., Olejniczak A., Zobowiąania - część ogólna, C.H. Beck, Warszawa 2010.

13. The new revenue recognition standard-brokers and dealers in securities. Technical Line, FASB - final guidance. Ernst \& Young, 2014.

14. Toshio I., Significance of realization principle in accounting, „The Annals of the Hitotsubashi Academy" 1959, 9.

15. Mourik van C., Katsuo Y., Articulation, profit or loss and OCI in the IASB Conceptual Framework: different shades of clean (or dirty) surplus, Paper for the IASR Research Forum, Brussel, 28.11.2017.

\section{LEGAL ACTS}

1. Ustawa z 23 kwietnia 1964 r. - Kodeks cywilny (tekst jedn. Dz.U. z 2017 r, poz. 459 ze zm.)

2. Ustawa z 29 września 1994 roku o rachunkowości (tekst jedn. Dz.U. z 2017 r., poz. 2342 ze zm.) 


\section{UMOWA Z PREMIĄ ZA SUKCES W ŚWIETLE MSSF 15 ORAZ POLSKIEJ USTAWY O RACHUNKOWOŚCI}

Warunkowy element ceny, zawartej w umowie z premią za sukces, jest częstym składnikiem umów zawieranych z klientami w niektórych sektorach. Stanowi on odroczony w czasie składnik ceny, który może nigdy (w całości lub w części) nie stać się wynagrodzeniem należnym. W związku z brakiem jednoznacznych zapisów w tym zakresie w polskim prawie i wejściem w życie MSSF 15, autorka podejmuje zagadnienie księgowego ujmowania tak określonych przychodów. Celem jest analiza zapisów MSSF 15 w zakresie umowy o dostawę z premią za osiągnięcie sukcesu na tle unormowań polskich regulacji rachunkowości. Weryfikowana teza zakłada, że choć obie regulacje są zgodne z podwalinami teoretycznymi rachunkowości, to każda odmiennie ujmuje ww. przychody. Cel osiągnięto za pomocą analizy regulacji MSSF 15, ustawy o rachunkowości oraz prezentacji przypadku praktycznego. Wyniki potwierdziły odmienne ujęcie przychodów w oparciu o dwie analizowane regulacje prawne oraz wskazały na dużą rolę szacunków w zakresie ujawnień przychodów według MSSF 15.

Słowa kluczowe: przychody, MSSF 15, umowa z premią za sukces.

DOI: $10.7862 /$ rz.2018.hss.78

Tekst złożono do redakcji: czerwiec $2018 \mathrm{r}$.

Tekst przyjęto do druku: grudzień 2018 r. 